\title{
NOTES
}

\section{CORPORATIONS: NEW YORK LIMITS POWER OF DIRECTORS TO BLOCK CORPORATE ACTION BY ABSTENTION FROM BOARD MEETINGS}

$M_{\text {INORITY directors sometimes abstain from board meetings in }}$ order to prevent a quorum from being formed and thus, in effect, prevent the board from taking any action. Heretofore no doubt has been expressed either by the courts or the commentators as to the propriety of such conduct. ${ }^{1}$

The use of this tactic, however, is limited by the recent New York case of Gearing $v$. Kelly. 2 There a director, to prevent a quorum from being formed, ${ }^{3}$ refused to attend a meeting called to fill a vacancy on the four-man board. The two remaining directors

1 Tomlinson v. Loew's, Inc., 36 Del. Ch. 516, 134 A.2d 518, af'd per curiam, 37 Del. Ch. 8, 135 A.2d 196 (1957); Campbell v. Loew's, Inc., 36 Del. Ch. 563, 134 A.2d 852 (1957). See also Zachary v. Milin, 294 Mich. 622, 293 N.W. 770 (1940), and Trendley v. Illinois Traction Co., 241 Mo. 73, 145 S.W. I (1912), holding that a director cannot be trapped into attending a board meeting. The policy behind the inability to trap a director and the absence of a duty to attend appear quite similar. Basic to each is the understanding that "there is no legal process by which a director of a private business corporation can be forced to attend a meeting." Id. at 94, 145 S.W. at 6.

A majority stockholder generally has the same fiduciary duty as does a director, Southern Pac. Co. v. Bogert, 250 U.S. 483 (1919), and courts generally allow such a stockholder to abstain from a stockholder's meeting. In the Matter of Pioneer Drilling Co., 36 Del. Ch. 386, 130 A.2d 559 (1957). Contra, Hill v. Town, 172 Mich. 508, 138 N.W. 334 (1912); cf. In re P. F. Keogh, Inc, 192 App. Div. 624, 183 N.Y. Supp. 408 (1920).

2 II N.Y.2d 201, 182 N.E.2d 391, 227 N.Y.S.2d 897 (5-to.2 per curiam decision), affirming 15 App. Div. 2d 219, 222 N.Y.S.2d 474 (1962), reversing 29 Misc. 2d 674, 215 N.Y.S.2d 609 (Sup. Ct. 1961). The corporation, Radium Chemical Company, Inc, was formed by Messrs. Kelly and Gearing, each owning one-half of the stock. These two and an employee constituted the board of directors. In 1952, at Mr. Gearing's death, Mrs. Meacham, petitioner, replaced her father on the board. In 1955, with Mrs. Meacham's approval, the board was enlarged and Mr. Kelly's son was added. This case concerns the resignation of the employee as director and the attempt to have her replaced by the son-in-law of the elder Kelly, thus making three of the four directors members of the Kelly family.

In absence of a controlling statute, charter provision, or by-law, the stockholders present at a duly called meeting, though a minority, constitute a quorum, BALIENTINE, Corporations $\$ 45$ (rev. ed. I946); SPELrMan, Corporate Directors 86 (1931), but a quorum does not. exist at a board meeting unless a majority of the directors are present. Calumet Paper Co. v. Faskell Show-Printing Co., 144 Mo. 331, 45 S.W. 1115 (1898); Morrill v. Little Falls Mfg. Co., 53 Minn. 37I, 55 N.W. 547 (1893), aff'd after retrial, 60 Minn. 405, 62 N.W. 548 (1895); Annot., 21 L.R.A. 174 (1893). The distinction is 
attended, "elected" a friendly fourth director, and thereby secured complete control of the corporation. Although section 25 of the New York Business Corporation Law allows the court either to confirm an election or to order a new one "as justice may require,"4 the minority director here sought to vacate the election. The trial court set aside the election because of the absence of a quorum. The Appellate Division reversed, holding that the director was estopped to contest the validity of the election since she had intentionally abstained from the meeting. ${ }^{5}$ Agreeing with this reasoning, the Court of Appeals held that the director could not complain of an irregularity which she had caused ${ }^{6}$ and therefore justice did

between a body of an indefinite number, i.e., stockholders, and a body of a definite number, i.e., boards of directors or trustees. Ibid.

However, once a quorum is present, the subsequent withdrawal of persons otherwise sufficient to prevent a quorum from being formed does not affect valid actions taken at the meeting after their departure, Hexter v. Columbia Baking Co., 16 Del. Ch. 263, 145 Atl. 115 (1929); Pennsylvania ex rel. Sheip v. Vandegrift, 232 Pa. 53, 81 Atl. 153; Annot., 36 L.R.A. (N.S.) 45 (1911), unless there is a controlling statute, charter provision, or by-law specifically requiring a majority vote for the specific action, Bridgers v. Staton, 150 N.C. 216, 63 S.E. 892 (1909); In Te Argus Printing Co., 1 N.D. 434,48 N.TW. 347 (1891).

N.Y. GEN. CORP. LAw \$25. This statute vests in the court only the power to confirm an election or order a new one. In re Election of Directors of Radiant. Knitting Mills, Inc, 20 Misc 2d 915, 194 N.Y.S.2d 232 (Sup. Ct. 1959). However, it. has been held that there is an implied power to vacate an election without ordering a new one, when the latter would be futile. Application of Katz, 2 Misc. 2d 325, 143 N.Y.S.2d 282, aff'd, 1 App. Div. 2d 657, 147 N.Y.S.2d 10 (1955). But see In Te William Eaehndrich, Inc, 2 N.Y.2d 468, 472 n.3, 141 N.E.2d 597, 599 n.3, 161 N.Y.S.2d 99, 102 n. 3 (1957).

The counterpart of $\$ 25$ in the new New York Business Corporation Law, $\$ 619$, removes this limitation by providing that the courts may "confirm the election, order a new election, or take such other action as justice may require." (Emphasis added.) N.Y. Bus. CoRp. Laws $\$ 619$ (effective Sept. 1, 1963).

- The Appellate Division, I5 App. Div. 2d 219, 222 N.Y.S.2d 474 (1962), alternatively held that a quorum was present by interpreting the by-laws to require, for a quorum, only a majority of the remaining directors and not a majority of the entire four-man board. The trial court, 29 Misc 2d 674, 215 N.Y.S.2d 609 (Sup. Ct. 1961), held to the contrary. The general rule is that, absent a contrary provision in the statutes, charter, or by-laws, the quorum is based on the entire board and is unaffected by vacancies. See Cirrincione v. Polizzi, 14 App. Div. 2d 281, 220 N.Y.S.2d 741 (1961); Barrentine, op. cit. supra note $3, \S 45$. The new New York Business Corporation Law is to that effect. N.Y. BUS. CoRp. LAw $\$ \$ 702$ (a), 707 (effective Sept, 1, 1963).

The new New York statute providing that vacancies may be filled by a majority of the remaining directors, though less than a quorum exists, may eliminate the problem presented in the principal case. N.Y. Bus. CoRp. LAw $\$ 705$ (a) (effective Sept. 1, 1963). But compare Tomlinson v. Loew's, Inc, supra note 1 , with In re Chelsea Exch. Corp., 18 Del. Ch. 287, 159 Atl. 432 (1932). The Model Act, twenty states, Puerto Rico, and the District of Columbia have similar provisions. Moder Bus. CoRP. ACT ANN. \$ \$6, If 2.02 (3) (b) (1960).

- The court also denied relief to a complaining stockholder, the director's mother, because she had encouraged and colluded with the director. If it is conceded that 
not tequire a new election. ${ }^{7}$ The court thus implied that there is!a duty to attend board meetings but failed to discuss this duty. The court also did not address. itself to the significance of the directox's motive for abstention although it may be inferred from the opinion, when taken in conjunction with the allegations of the respective parties, that motive was of dispositive importance. ${ }^{8}$

$\therefore$ In prior decisions allowing a director's abstention from board meetings, the motives of.the director have not been controlling. In the leading cases on this point, Tomlinson v. Loew's, Inc.10 and Campbell. v. Loew's, Inc., ${ }^{11}$ two factions, neither constituting a quorum of the board of directors, were fighting for control of a large

the director should not be allowed to complain, the court's action in denying relicf to the stockholder is supported by sufficient authority. $G$. Brusha v. Board of Educ, 41 Okla. 595, $139 \mathrm{Pac} 298$ (1913). But see McFaddèn v. Allen-Nelson Mill Co., Ib0 Wash. 249, 272 Pac. 714 (1928).

"Where a quorum is not present an election is illegal. 2 FLetches, Cyclopedis of Private Corporations $\$ 428$ (rev. vol. 1954). It has been held that "as justice may require $^{\prime 2}$ is considered only if the election was legal and the complainant can show that a new election would correct an inequitable result; but that where an election is shown to be illegal "there is no election and justice requires no further showing." In re Green Bus Lines, Inc, 166 Misc. 800, 804, 2 N.Y.S.2d 556, 560 (1937). Gf. In rec Lake Placid Co., 274 App.-Div. 205, 81 N.Y.S.2d 36, motion for leave to appeal denied, 298 N.Y. 932, 82 N.E.2d 44 (1948) (quorum not present, court invalidated election without a showing that justice so required).

8 'The respondents alleged that the director was attempting to frustrate respondents' management of the corporation until her inexperienced husband was elected to fili the vacancy on the board and was given a salary equal to that received by the younger Kelly, president of the corporation. Brief for Respondents, pp. 2.6. Gearing v. Kelly, 11 N.Y.2d 201, 182 N.E.2d 39l, 227 N.Y.S.2d 897 (1962). By characterizing the director's conduct as an "intentional and deliberate" attempt "to paralize the board," the court appears to have been persuaded by respondents' allegations. 11 N.Y.2d at 203, 182 N.E.2d at 391,227 N.Y.S.2d at 898 . This finding seems untenable in view of the fact that the director had agreed to attend any board meeting which had a stipulated agenda precluding a filling of the vacancy. Il N.Y.2d at 205, 182 N.E.2d at 392, 227 N.Y.S.2d at 899 (dissenting opinion).

In Britain the corporate practice-is to have a low quorum, but a closed agenda at stockholder meetings. Gower, Some Contrasts Between British and American Gorporation Law, 69 HARv. L. REv. 1369, 1391 (1956).

- However, in the campbell case, the court indicated that the motive for abstention may be a factor to consider by saying.

While a concerted plan to abstain from attending directors' meetings may be. I improper under some cixcumstances, I cannot find that the fact that the so-called $x:$ Vogel directors did not attend directors' meetings called to take action which would give an opposing faction an absolute majority of the board-solely . because of director resignations-is such a breach of their fiduciary duty that they should.be judicially compelled to attend board meetings.

Campbell v..Loew's, Inc., 36 Del. Ch. 563, 587, 134 A.2d 852, 866 (1957). But of. Stóne v. Auslander, 28 Misc. 2d 384, 212 N.Y.S.2d 777 (Sup. Ct. 1961). (19 $(1957):$

36 Del. Ch. 516, 134 A.2d 518, aff'd per curiam, 37 Del. Ch. 8, 135 A.2d 136

$\because$ :11 36 Del. Ch. 563, 134 A.2d 852 (1957). 
public issue corporation. The majority faction met, elected directors to fill certain vacancies and sought to have the Delaware Chancery Court declare the election valid, despite their.non-compliance with the quorum requirement. In denying the majority's petition Chancellor Seitz held that no sanction could be based upon the opposing faction's refusal to attend a director's meeting, notwithstanding their clear.intent to prevent the board from taking any action.

- In comparing Gearing with the Loew's cases, two things must be considered. First, unlike the Loew's cases, Gearing v. Kelly involved a close corporation. ${ }^{12}$ Second, high quorum requirements, which are designed for close corporations, cannot be successfully utilized unless directors are allowed to refrain from attending a particular board meeting. Having said this, and noting that Loew's allowed a director of a public issue corporation to freely abstain from a board meeting, it would appear logical for the court to have followed the same rule in Gearing v. Kelly.

- In considering the greater need for high quorum requirements and. other protective devices in the close corporation. its cnaracteristics should be carefully distinguished from those of the public issue "corporation. Persons entering into these "chartered partnerships"13 do so primarily to obtain limited liability and the tax advantages incidental to the corporate form, while operating the business as if it were a partnership." In these "incorporated partnerships,"14 a per: son not having a large bloc of distinterested stockholders to whom he can appeal must have means by which he can prevent his relega; tion to an ineffective minority position. Investment in a close corporation usually represents a greater portion of a person's wealth than does investment in any one public issue corporation. The possi-

12 One of the reasons that legislatures have not enacted statutes specially adapted to the close corporation has been the difficulty in defining that entity. Iatty, The Close Corporation and the New North Carolina Business Corporation Act, 34 N.C.L. REv. 492 (1956): For sóme suggested definitions see Winer, Proposing a New York 'Close Corporation Law' 28 CorNel工 I.Q. 313, 314 (1943); Israels, The Close Corporation and the Law,-33 ConNeLr L.Q. 488 (1948). The North Carolina Business Corporation Act, without trying to define a close corporation, is designed to accommodate this corporate form and did so by limiting its application in certain instances to a coiporation; the stock of which is not generally traded. N.C. GEN. STAT. \$ 55-73 (b) (1960): For a discussion of this definitional difficulty, see 1 O'NEAL, GLOSE CorporAtJons $\$ 1.02(1958)$.

${ }^{13}$ Ripin v. United States Woven Label Co., 205 N.Y. 442, 447, 98 N.E. 855, 856 (1912). - "Cuppy v. Ward, 187 App: Div. 625; 639, 176 N.Y. Supp. 233, 243 (dissenting opinion), aff'd per curiam, 227 N.Y. 603, 125' N:E. 915 (1919). $\because \cdots$ 
bility of a squeeze-out ${ }^{15}$ and the difficulty of disposing of these holdings necessitate the availability of protection. Persons in a close corporation frequently want to. control expenses, limit the nature of the business, regulate the distribution of profits, ${ }^{16}$ or determine the admission of other persons to the firm. ${ }^{17}$ Based solely on these policy considerations, it would appear that protective devices ${ }^{18}$ serve a more useful purpose in the close than in the public issue corpora. tion.

The courts should not impede the desire to obtain beneficial features of both corporate and partnership structures when neither the stockholders, the creditors, nor the public are damaged thereby.10 Statutes have been passed which obviously understand and foster these ambivalent desires. ${ }^{20}$ Since the legislatures are willing to countenance these objectives, it is difficult to understand why the New York court failed to show the same degree of empathy.

Admittedly, the use of protective devices increases the possibility

\footnotetext{
${ }^{25}$ See generally O'NeAt and Deriyin, Expursion or OPPREssion of Business Assoct* ATES (1961).

${ }^{10}$ In a close corporation, profits are generally distributed through salaries and there. fore persons actively engaged in the business desire to insure the receipt of a good salary. If, however, an investor in the corporation is not working in the business, he will want to make sure that substantial dividends are paid so that he will receive a satisfactory return on his investment.

${ }^{27}$ Retrictions on stock transfers so that the corporation gets a first-option can successfully control admissibility of other persons, O'Neal, Restrictions on Transfer of Stock in Closely Held Corporations: Planning and Drafting, 65 HAnv. L. REv. 773 (1952), while pre-emptive rights will perpetuate a stockholder's original degrec of control. For a discussion of the development of pre-emption, see Drinker, The Pre. emptive Right of Shareholders to Subscribe to New Shares, 43 HARV. L. REv. 586 (1990).

${ }^{38}$ Typical protective devices are: (I) high vote and high quorum requirements, (2) voting and non-voting shares, (3) class voting for directors, (4) stockholder agreements, (5) voting trusts, and (6) irrevocable proxies. 1 O'NeAl, Crose Conporstions $\$ 4.05$ (1958). For a full discussion of high vote and high quorum requirements, sec Id. ch. 4 .

${ }^{20}$ For the opinion of an enlightened court see Kaufman v. Meyberg, 59 Cal. App. 2d $730,739,140$ P.2d 210, 215 (1943), where the court said: "[T]0 permit the technical rules as commonly applied to corporations to be apphed in the case of a close family corporation of two shareholders of equal ownership, would serve to defeat such equality of ownership, impede justice and perpetuate fraud." For a discussion of desirable statutes, see Winer, supra note 12 . For an analysis of the North Carolina Business Corporation Act, N.C. GEN. STAT. $\$ \S 55-1$ to 55-175 (1960), which, without express designation, was enacted to accommodate the close coxporation, sec Latty, supra note 12.

${ }^{20}$ See, e.g., Moder Bus. Corp. Act AN. $\$ 37$ (1960); ILr. ANn. Stat. ch. 32, § 157.87 (Smith-Hurd Supp. 1961); PA. StaT. ANN. tit. 15, \$2852-402 (5) (1958). See generally Cary, How Illinois Corporations May Enjoy Partnership Advantages: Planning for the Closely Field Firm, 48 Nw. U.L. REv. 427 (1953).
} 
of corporate paralysis. or the extortion of selfish concessions. ${ }^{21}$ These factors, however, should be the concern not of the courts, but of the corporate participants. They realized these limitations, but deemed it best to protect their interests by resorting to protective devices. It must be remembered that in a close corporation persons generally expect to be able to protect their interests in just such a fashion. If a court is preoccupied with the fear of corporate paralysis, as apparently was the situation in the instant case, its decision will be disproportionately influenced by a result the shareholders were willing to risk, but will ignore an objective-protection-which the shareholders were more desirous of securing.

The attitude of the court in tampering with an accepted corporate practice is reminiscent of the attitude evinced in Benintendi $v$. Kenton Hotel,22 an earlier New York case, where high quorum and high vote requirements embodied in the by-laws of a close corporation were declared invalid as inconsistent with corporation law and public policy. Though such provisions are still invalid if placed in the by-laws, ${ }^{23}$ the legislature, by enacting statutes which allow such provisions to be put in the charter, ${ }^{24}$ has exhibited a realization of the necessity of treating close corporations as "chartered partnerships," and has thus fostered veto provisions as a means

21 Protective devices also have certain limitations whether used in the close or the public issue corporation. They do not allow a minority stockholder to take affirmative action in the development of corporate policy and they hinder flexibility in adapting to changiug circumstances. O'Neal, Giving Shareholders Power to Veto Corporate Decisions: Use of Special Charter and By-Law Provisions, 18 LAw \& CONTEMr. PROB. 45l, 471-72 (1953).

23294 N.X. 112, 60 N.E.2d 829 (1945). See also Kaplan v. Block, 183 Va. 327, 31 S.E.2d 893 (1944) (invalidated charter provision requiring unanimous approval for board action).

2s Thus, in effect, Benintendi, as strictly interpreted, is still followed. Compare In re William Faehndrich, Inc. 2 N.X.2d 468, 14I N.E.2d 597, 161 N.Y.S.2d 99 (1957) (invalidated two-thirds quorum requirement in by-laws) with In re Election of Directors of Radiant Knitting Mills, Inc, 20 Misc. 2d 915, 194 N.Y.S.2d 232 (Sup. Ct. 1959) (upheld charter provision requiring unanimous vote of board).

${ }^{24}$ N.Y. Stock Corp. LAw \$9. See 62 HARV. L. REV. 526 (1949) for a discussion of $\$ 9$, the Iegislative response to Benintendi, which recognized the close corporation as alkin to both the partnership and the public issue corporation, but significantly different from each. The new New York Business Corporation Law, as did \$9 supra, authorizes the charter to require that quorum and vote requirements for directors' action, N.Y. Bus. CoRp. LAw $\$ \$ 709$ (a) (1) - (2) (effective Sept. 1, 1963), and for stockholders' action, Id. $\$ \$ 616($ a) (1) - (2), be greater than a simple majority.

However, the Law Revision Commission's Reports suggested that $\$ 9$, and pre. sumably the new statutes, changed the result, but not the reasoning, of Benintendi. Barer \& Cary, Cases on Corporations 294 (3d ed. 1958). 
of furthering the wishes and protecting the interests of investors in close corporations.

Eowever, there:may be some question as to the wisdom of a high quorum requirement as a means of protecting minority stockholder interests. .Such a protective device dișeourages attendance of a dissident minority and thereby militates against the discussion of differences and the possibility of arriving at a compromise. Moreover, it prevents consideration not only of the controverted subject matter but also of other matters which normally would come before the meeting. Though high quorum and high vote requirements provide more flexible protection, when used together, they nevertheless cannot be utilized simultaneously. If a person goes to a meeting relying on the high vote requirement as a protective device, then the high quorum requirement is of no benefit; and if he abstains from the meeting because of the latter, then he cannot take adviantage of the former. ${ }^{25}$

In upholding the contested election, the New York court failed to discuss a director's duty of attendance, upon which the holding seems premised, and to support its holding either by precedent or reasoned discussion. However Gearing $v$. Kelly, while casting doubt on the availability of abstention to defeat a quorum, nevertheless may provoke beneficial inquiry into the desirability of high quorum requirements as an effective safeguard of minority. stockholder and director interests.

${ }^{25}$ See 1 O'Neaz, Close Corporattons $\$ 4.22$ (1958). 